\title{
ON SHADOW AND FORM: KOREAN NATIONALISM'S DIGRAPHIC CONFLICT
}

\author{
William Strnad \\ Adam Mickiewicz University \\ Korean Language Department \\ al. Niepodległości 4 \\ Poznań, Poland \\ wjstrnadiii@yahoo.com
}

\begin{abstract}
This paper is an examination of the many points of intersection between Korean nationalism in both Koreas, and Chinese characters (Hanja), as well as a contextualization of the historical and, at times, antithetical relationship or binary consisting of Hanja and Han'gŭl (Chosŏn'gŭl). Emerging from liberation the two Korean states over the next several decades would "engage" Hanja with diverse and fluctuating positions and approaches at different times. These responses have ranged from the abolition of Hanja or the enforcement of Han'gŭl (Chosŏn'gŭl) exclusivity, to the re-establishment and strengthening of Hanja education. Koreans for over a century have responded to "issues of script" based on socially-created narratives. This phenomenon can be viewed through constructivist paradigms, or can be interpreted as implemented pragmatic policies exemplifying instrumentalist nationalism. This paper's assertion is that Korea's vacillating response regarding Korean nationalism's digraphic conflict is eloquent of the complex confluences that formed Korean ethnic nationalism, and therefore, Korean national identity.
\end{abstract}

Key words: Korean ethnic nationalism, constructivism, instrumentalism, Chinese characters (Hanja), Han'gŭl (Chosŏn'gŭl) exclusivity

\section{영(影) 및 형(形)에 관하여: 한국(조선)민족주의의 이중(二重)문자 갈등}


개요: 본 논문은 남북한의 민족주의와 한자 사이의 많은 교차점을 분석하는 것뿐만 아니라, 한자와 한글(조선글) 간의 역사적 때때로는 상반되는 관계 및 이중성을 맥락화하는 것이다. 해방 후 수십 년 동안 남북한의 한자에 대한 입장과 정책은 다양하게 변화해 왔고, 그것은 한자폐지 혹은 한글(조선글)전용의 강제로 시작하여 한자교육의 재건이나 강화 등으로 나타났다. 한 세기 이상에 걸쳐 한국(조선)인들은 “문자의 문제”에 대해 사회적으로 이루어진 내러티브에 입각하여 반응했다. 이 현상은 구성주의 패러다임을 통해 볼 수 있으며, 또는 도구적 민족주의를 증명하는 실용 정책의 구현이라 해석될 수도 있다. 본 논문은 한국(조선) 민족주의의 이중(二重) 문자 갈등에 관한 변동적 반응이 한국(조선)의 민족주의 즉, 한국(조선)의 정체성을 형성해 가는 복잡한 합류점임을 밝힌다.

주요단어: 남북한의 민족주의,구성주의, 도구주의, 한자, 한글(조선글)전용

\title{
W CIENIU I FORMIE: KONFLIKT DWUZNAKÓW W KOREAŃSKIM NACJONALIZMIE
}

\begin{abstract}
Abstrakt: Niniejszy artykuł stanowi wieloaspektowy przegląd „punktów stycznych” między koreańskim nacjonalizmem w obu Koreach a chińskimi znakami (Hanja). W tym aspekcie ukazuje również kontekstualizację historyczną, wystepujący niekiedy przeciwstawny wiązek czy istniejącą „podwójność”, która składa się z Hanja i Han'gŭl (Chosŏn'gŭl). W powstałych po wyzwoleniu dwóch państwach koreańskich w ciągu kolejnych kilku dekad znaki chińskie były nadal stosowane różnorodnie w różnym czasie. Zastanawiano się nad zniesieniem (likwidacją) Hanja i wprowadzeniem wyłącznie pisma koreańskiego, jak i nad przywróceniem i umocnieniem edukacji Hanja. Koreańczycy od ponad wieku odnoszą się do „kwestii pisma” w oparciu o społecznie tworzone narracje. Zjawisko to może być rozważane (analizowane) przez paradygmaty konstruktywistyczne lub może być postrzegane (tlumaczone) jako wprowadzenie pragmatycznych zasad ukazujących instrumentalny nacjonalizm. W kontekście koreańskiego nacjonalizmu pokazano konflikt dotyczący stosowania $\mathrm{w}$ Koreach dwuznaku (podwójności pisma: Hanja i Han'gŭl (Chosŏn'gŭl), co powiązane jest $\mathrm{z}$ kształtowaniem się koreańskiego nacjonalizmu etnicznego, a zatem i koreańskej tożsamości narodowej.
\end{abstract}

Slowa kluczowe: Koreański nacjonalizm etniczny, konstruktywizm, instrumentalizm, znaki chińskie (Hanja), pismo koreańskie Han'gŭl (Chosŏn'gŭl) 
1. Nation, National Identity and Nationalism

A nation and its national identity, and therefore, its nationalism, are "historically contingent, context-driven, and defined and redefined in negotiation and transaction". (Jenkins 1997: 143) Korean nationalism, essentially a form of ethnic nationalism, remains a key organizing principle of Korean society, both North and South. Korean nationalism, depending on context, has been described as exhibiting the following characteristics: anti-imperialism, post-colonialism, anticommunism, diaspora nationalism, and state nationalism. Shin GiWook rejects extreme notions of primordialism related to Korean ethnic nationalism, and has observed that the concept of a modern construction of Korean nationalism is similar to that of other nations emerging during the late nineteenth and early twentieth centuries. Shin's caveat, however, is that Korean nationalism was embedded in a particular social reality and history, the essence "without which, Korean nationalism cannot be conceptualized". (Shin 2006: 8-10)

In this paper, the author agrees with the premise that Korean nationalism is essentially ethnic and that this ascribes a shared identity. However, beyond that assumption the constructivist and instrumentalist approaches related to nationalism and political behavior overlap and can serve to refine inquiries into the policies and programs of both Koreas pertaining to issues related to scripts.

Constructivism is a theory that political behavior of state actors can be understood as largely socially constructed. Scholarly arguments are as follows: (1) cultural elements, mainly norms, shape the national interests and state policies; or both (2) cultural or institutional elements of states' global or domestic environments, mainly norms, shape state identity; (3) variations in state identity, or changes in state identity, affect the national interests, policies of states, or both; (4) configurations of state identity affect interstate normative structures, such as regimes or institutions; and (5) state policies both reproduce and reconstruct cultural and institutional structure. (Jepperson et al. 1996: 52-53) Alexander Wendt (1992: 398) writes that "identities are the basis of interests", and "actors define their interests on the process of defining situations". National identity defines "the group that the state is supposed to serve and protect", and therefore, defining a na- 
tional identity is associated with national objectives that the state is expected to champion. (Horowitz et al. 2007: 3-4) This suggests that national identity provides a "cognitive framework for shaping its interests, preferences, [and] worldview." (S. S. Kim 2004: 41-42)

Identity is the most fundamental concept that constructivists use, and is constituted in relation to difference. The process of acquiring a specific identity is termed "identification", and it proceeds at the same time with the process of differentiation. William Bloom (1993: 51-52) describes identification as a mechanism for internalizing attitudes, mores and behavior, which in turn, can evoke a shared group identification through meaningful and real experiences. Identification can be made only if the situation or environment is positive and beneficial to an individual or a group. Popular support for any identification comes only if the identification provides a meaningful interpretation of an experienced reality.

Bloom's observations are a logical transition in considering instrumentalism as it pertains to the topic of this paper. Instrumentalism, related to the actions of state actors, is defined as a group or nation's use of identity as a means of mobilization and as a tool of to achieve their interests. Inherent in this general description is an emphasis on analysis of material interests (economic, defense and security), interests that ultimately correlate with political motivation and consequentialist ethical reasoning. Ernst B. Haas, while recognizing the socially constructed nature of modern nationalism, assumes "the dominance of instrumental motives among actors", further elaborating that state actors "choose to act as nationalists for instrumental reasons". (Haas 1997: 34) Language is a cornerstone of identity in the context of modern nationalism. Eric Hobsbawm's conclusion (Hobsbawm 1996: 1078) is that language has the potential for "political self-assertion". This seems to support the logic of a reverseengineered intuitive explanation that political self-assertion can enlist language in the achievement of political goals.

2. Modern Korean Nationalism and the Politics of Language (prior to 1945) 
It is essential to underscore the historical relationship between Hanja and Han'gŭl exclusivity (Han'gŭl chŏnyong) as it is referred to in the South, or Chosŏn'gŭl exclusivity (Chosŏn'gŭl chŏnyong), as is expressed in the North, at least within the parameters of this article. Modern Korean nationalism begins to form in the late nineteenth century as a reaction against the foreign incursions into the country. The Tonghak Peasant's Uprising of the 1890s, which precipitated the First Sino-Japanese War, was a conservative uprising against local scholarofficial abuses. There were, however, powerful anti-foreign elements in Tonghak rhetoric, stemming, in part, from the Japanese mercantile penetration of the Korean economy of the late nineteenth century. The Kabo Reforms (1984-1896) officially brought to an end the civil service examination system predicated upon mastery of Hanja and classical Chinese texts. Han'gŭl was touted as the new official script. (Eckert et al. 1990: 225)

Michael E. Robinson has described the publication of The Independent (1896-1899), and its use of Han'gŭl, as "a deliberate statement of cultural unity and linguistic identity." (Robinson 2007: 24) Chu Si-gyŏng, a language scholar and minister of education during the Empire of Korea period, first advocated the eradication of Chinese characters and the installment of Han'gŭl as the exclusive orthography for Korean daily newspapers in 1897. Chu and other Korean language purists based their promotion of a Han'gŭl-only policy on a belief in the superiority of the native Korean language and script over foreign languages and scripts (Janasiak 2012: 223; Park 1989: 118-119, cited in Lovmo 1999) the rhetoric of which is still occasionally used in both Koreas. Chu wrote that ending the use of Hanja and perfecting the use of Han'gŭl was the principle means for "ending the habit of aristocratic cultural slavery to Chinese culture". (Robinson 2007: 34)

With Korea's independence from Chinese political hegemony at the turn of the century, the Han'gŭl-only movement grew with the formation of modern Korean nationalism, constituting a linguistic nationalism (in the case of Korea, Han'gŭl or Chosŏn'gŭl nationalism). (Song 1994: 206) By 1900, the use of classical Chinese as a written form of official communication was popularly seen as not being modern and a symptom of cultural dependence, reflected by the then growing use of the term sadaejuüi ("serving the great") (Robinson 1988: 34), referring to what had been Korea's relationship with China. In 1907, Chu Si-gyŏng published "Essay on Korean Language 
and Letters" in which he lamented the failure to widely use Han'gŭl to "transform the thoughts and broaden the knowledge of the entire population". For Chu and many other Korean scholars in the early twentieth century, the use of Han'gŭl was synonymous with creating a new and truer identity as a nation; a corollary was that Hanja was an obstacle to the achievement of that identity. (Shin 2006: 37)

The Japanese colonial period (1910-1945) was awash with attempts to impose rigid political, social and cultural controls over the Korean population. After the widespread protests and social unrest of the March First Movement of 1919, the Japanese government instituted a "cultural policy" (bunka seiji), which allowed for a reopening of the public sphere in colonial Korea. (Eckert et al. 1990: 278; Robinson 2007: 66) In 1921, Korean language scholars formed the Korean Language Research Society (Chosŏn'ŏ yŏn'guhoe, later the Korean Language Society, or the Hangŭl hakhoe), which led the movement to purify the Korean language, including championing Han'gŭl exclusivity. The Korean language movement was a prominent nationalist project that attempting to maintain Korean cultural identity in the face of colonial racism. The movement prospered during the 1920s and 1930s and was associated with linguistic and literary research and publications, as well as mass literacy movements (in Han'gŭl) supported by the Japanese colonial administration to increase the literacy of the Korean population (Robinson 2007: 65-67) until 1934.

After the implementation of the cultural assimilation policies of Japan in the mid-1930s, which attempted to extirpate Koreans of their national identity, the activities of the Korean language movement continued, despite the allegedly "provocative" nature of their work, such as the publication of Han'gŭl materials. Numerous members of the Korean Language Research Society were jailed in 1942, where many of them died. (King 2007: 209-210; Song 2001: 132; Robinson 2007: 67) At one trial, Korean language scholars were charged with the crime of "working to ensure the future independence of Korea by reviving the national spirit (kukhon) and fostering national strength through a cultural movement". (H. S. Lee 1973: 41, cited in Robinson 2007: 68) According to Mark Peattie, one of the central assumptions of Japanese racism and assimilation pertaining to the Korean colony was the "same script, same race" (dōbun dōshu) paradigm that hearkened back to late nineteenth century Pan-Asian ideology of racial and cultural affinities of nations in the Sino-centric sphere juxtaposed 
against Western nations. (Peattie 1984, cited in Shin 2006: 42) The assimilation policies of the Japanese occupiers promoted Korean nationalism to be characterized by a distinctively Korean-centered view of East Asia. (Shin 2006: 42)

Shin Gi-Wook (2006: 116-119) has described the emergence of modern Korean nationalism as consisting of two periods with different narratives. Shin argues that in the period of the 1890s to the years prior to the start of Japanese occupation in 1910, Korean nationalism was predicated upon the universalist values of modernization, in national response to the collapse of the Sino-centric world and the increasing influence of foreign powers; in the second period, emerging toward the end of the first decade of the twentieth century, Korean nationalist's central narrative was dominated by particularism in the form of ethnicization of Korean nationalism as Japan strengthened its domination of Korea. (Shin 2006: 39-40; Haarmann 1993: 154-157)

The foundational components of modern Korean nationalism are relevant to the formation of narratives concerning an often oppositional relationship between Hanja and Han'gŭl: Han'gŭl was symbolic of both modernity and/or the essence of "true" Korean identity, whereas Hanja became associated with the contradictions of premodern Korea: political incapacity and foreign domination by China, and a rich heritage of scholarly brilliance. The historical HanjaHan'gŭl binary came to be defined along divides within Korean identity itself, and has continued to recapitulate for over a century.

3. Script Binary in the Two Koreas

\subsection{North Korea}

The character of the five years after liberation in the northern part of the Korean peninsula has been described by Charles K. Armstrong as "revolutionary". (Armstrong 2003: 241) Contributing to the profound 
transformation in the North was the political orientation and approaches of the Soviet Union's occupation of Korean north of the thirty-eighth parallel. The Soviet communist's ideological predisposition to conceptualize the desires of post-colonial peoples for revolution made their administration seemingly more attuned to the aspirations of the Korean people. The Soviet occupation forces expeditiously saw to the surrender of Japanese forces and the expulsion of Japanese persons from the North to Japan. The emphasis on economic and social justice for the masses, albeit totalitarian, was generally supported, except for targeted groups, such as large landowners, wealthy merchants, Christians, and those Koreans who had "collaborated" with the Japanese occupation government. (Weathersby 1993: 16)

The Soviet Civil Administration (Grazhidanskia Administratsiia) recognized the legitimacy of the popular "people's committees" which had come into existence in the late summer of 1945, using these organizations as a means of refining political control. (Eckert et al. 1990: 330-331; Weathersby 1993: 5) The rapid and thorough implementation of Soviet-supervised land reform in 1946, in which lands of what had been seen as exploitive large landowners were redistributed to former tenant farmers was a fulfillment of long-held desire for social and economic reform. The reaction of most Koreans in the North to this program was a sense of "post-colonial" rectification, and highlighted the convergence of Korean aspirations and the politics of liberation and revolution espoused by Soviet forces who occupied the North until 1948. (Armstrong 2003: 38-47; Cumings 1981: 384-396)

One advantage of the Soviet occupation forces was the number of Korean interpreters. According to Andrei N. Lankov, by early 1946, there were some 140-150 Soviet Koreans in Soviet occupied Korea. (Lankov 2002: 118) Other figures for actual Korean-speaking Soviet Koreans range from an estimate of approximately 300 (Suh 1967: 317, cited in Cumings 1981: 554), to "thousands" of interpreters virtually all of whom were from a long-established Korean-Soviet population. This language connectivity with the population was better enabled the Soviet Union's rapid rendering of assistance in a variety of projects designed to enhance Korean economic and technical recovery, projects often utilizing Soviet Korean civilians. (Scalapino and Lee 1972: 318 and 383)

The issue of illiteracy was of concern for both emerging centers of political power in a divided Korea. Two Japanese surveys of 
Korean literacy among the adult population during the Japanese occupation period, conducted in 1930 and 1944, indicated the literacy rate in Korea to be no higher than approximately 23 percent. In 1945, at the time of liberation, only 35 percent of school-age children were attending primary and secondary schools in newly liberated Korea, this out of a population of 21 million; an additional 3.5 to 4 million Koreans were living in the Korean diaspora by the end of the war. (Caprio and Jia 2009) One-fourth of the population in North Korea, an estimated 2,300,000 people, were counted by the new government as illiterate (Song 2015: 482-483), though some statistics put the number as high as 2,500,000. (Popov 1958: 194, cited in King 2007: 210-211)

"Eradication of Illiteracy" programs were instituted during and after the formation of the North Korean state under the leadership of Kim Il Sung. As part of these programs Chinese characters were identified as impediments in quickly achieving literacy, as the native phonetic alphabet was infinitely easier to master. (Kumatani 1990: 90) The impetus in the North was greatly hastened by the efforts of a Korean communist who had been living in China, Kim Tu-bong. Kim, who returned to Korea in 1946 and who was a noted linguist and disciple of Chu Si-gyŏng, pressed the emerging North Korean leadership to implement Chosŏn'gŭl exclusivity. (C. G. Kim 2006: 36) By September 1946, there were some 10,000 schools of national writing (Chosŏn'gŭl) operating in the North. During the winter of 1947/1948, an estimated 951,320 people learned to read and write Korean. (Popov 1958: 195, cited in King 2007: 211)

The elimination of Hanja was consistent with communist ideology, since Chinese orthography was considered as "property of only a few, [and as]...feudalistic". (C. W. Kim 1978: 167, cited in Lovmo 1999; Song 2015: 483) For North Korea, the elimination of illiteracy (and Chinese characters) was "an essential prerequisite to enable the party and the government to spread their policies among the people". (Kumatani 1990: 91) In 1947, newspapers began printing without the use of Hanja; by 1949, Kim Il Sung had ordered the total eradication of Hanja, making temporary exceptions only in the case of classical references, scientific and proper names, and then only in parentheses. (Kumatani 1990: 91-92) The government evidently understood the necessity to augment people's understanding of the meaning these Sino-Korean words through the temporary use of Chinese orthography. The efforts to eliminate Hanja during this period is thought to 
have encouraged the study of Chosŏn'gŭl, which in turn helped the North achieve a literacy rate for virtually all adults by the end of 1948 . (C. W. Kim 1978: 166, cited in King 2007: 211) North Koreans who were opposed to the full abandonment of Hanja (because of the resulting confusion in the vocabulary system) were dealt with by being publicly denounced as "the remains of the overthrown exploiting class, sectarian factors deeply influenced by flunkeyism, doctrinism, and reactionaryism". (Lovmo 1999)

The political climate in North Korea following the signing of the armistice in July 1953 is relevant to the official encouragement of Chosŏngŭl exclusivity. In post-Korean War North Korea, with the ongoing process of collectivization, the membership in the Korean Worker's Party expanded greatly, from 750,000 at the end of hostilities in 1953 to $1,164,945$ by 1 January 1956 . Collectivization of agriculture implied a reorganization of the local bases of political power. By April 1956, 56.8 percent of party members were from the poor peasant class. (J. W. Kim 1975: 184) A recognized need for literacy skills beyond the basics to mass indoctrination and mobilization was behind the program. The majority of new party members were from the poor peasantry, which suggested lower levels of education and higher rates of marginal literacy. Politically, the official elimination of Hanja in North Korea was sensible given the need of Kim Il Sung to solidify his political power base among the new political cadre.

The symbol of the Korean Worker's Party displays the societal elements of the Korean socialist state and is suggestive of an irony in post-Korean was North Korean that merits mentioning. Contained in the symbol are: the sickle (agriculture, farmers (nongbu)), the hammer (industry, laborers (kŭlloja)), intersected by a vertical brush (civil service, technocrats (samuwŏn)), while the party cadre (kanbu), are implied by the symbol in its entirety. A legacy of Korean history was the traditional desire of Koreans, both North and South, to hold office. This terminal value had been perpetuated by the civil service exam (kwagó) system, based on mastery of Chinese characters and classical Chinese learning. After 1953, farmers increasingly left the agricultural sector to become technocrats, and by 1958, with the party ranks swollen to 12 percent of the adult population, the technocrats were estimated to be as much as 20 percent of the adult population. During the commencement of the Chŏllima Movement, as much as 50 percent of the technocrats were transferred to the industrial and agri- 
cultural sectors to alleviate widespread labor shortages. (J. W. Kim 1975: 195-196; Szalontai 2005: 118-122)

Until 1948, North Korea had used mixed script in its official texts including its party newspaper, the Rodong Sinmun. That year, Kim Il Sung ordered the Workers' Party to stop using mixed script (Kukhanmunjongyong) and start using Han'gŭl exclusively. Although Hanja had been abolished from official texts, North Korea continued to have Hanja education in the years following the signing of the armistice in 1953. During this time, elementary and middle school students were supposed to be taught 600 characters and high school students were to be taught additionally 1,200 characters, with an ultimate goal of 2,400 characters for university students. (M. S. Kim 1999) Even after 1956, when the People's Republic of China adopted simplified Chinese characters (kanch'eja), North Korean schools continued to teach traditional Chinese characters (chöngja), as it has done until to the present. (Kuiwon 2014)

The transnational rhetoric of communism has been described as having been used by Korean revolutionaries as a means of achieving national objectives: liberation and independence. Korean communists were strongly nationalistic. Kim Il Sung's nationalist rhetoric reflected this tendency, and included concepts of restoring the "purity and unity" of the Korean people. Anti-colonialism and antiimperialism were the foundations of the establishment of the North Korean nation-state. (Shin 2006: 152-156) Kim Il Sung's own evolving position on Chosŏn'gŭl exclusivity versus maintaining Hanja in the national educational curriculum demonstrates the conflict inherent in the Korean script binary as it relates to Korean nationalism.

Despite the official pronouncements of Chosŏn'gŭl exclusivity from the founding of the Democratic People's Republic of Korea in 1948, the North Korean regime exhibited continued desire to instruct Hanja as exhibited by the 1959 publication of the Chinese Character Textbook (Hanmun kyogwasŏ), which was designed to instruct eighth to tenth grade students on Sino-Korean terms in mixed script. (Hannas 1997: 67) Kim Il Sung wanted to maintain cultural links with overseas Koreans and because it was needed to have mastery of Cultured Language. (King 2007: 213) It seems reasonable, that these cultural links were in no small measure related to the Korean residents of Japan (Zainichi) which was a source of financial support and legitimacy in the legitimacy war between the two Koreas, particularly through the 
pro-North General Association of Korean Residents in Japan (Chōsen Sōren). (Shipper 2010: 59-60)

Of historical importance to Hanja use and education in the North are the two "conversations (kyosi) with linguists" conducted by Kim Il Sung in 1964 and 1966. In the 1964 conversation, Kim noted that the presence of Hanja in South Korean newspapers and books suggested that North Korea, in order to be aware of developments in the South, should strengthen the teaching of Hanja (M. S. Kim 1999) for the purposes of achieving unification. (C. J. Kim 2006: 37) Kim Il Sung had concluded that with Chosŏn'gŭl exclusivity being the new policy, there were clear indications that Hanja education was often neglected. In the same 1964 conversation, Kim announced his intention to reintroduce Hanja education, lamenting that university graduates in North Korea had a difficult time with Korean language because of their lack of Hanja knowledge. (Hatori 1991: 270, cited in King 2007: 213-214)

In 1966, Kim Il Sung ordered that Hanja instruction be reinstituted as part of the curriculum in North Korean secondary education. In 1968, the government in P'yŏngyang established a required standard of 2,000 characters to be taught from the first year of North Korean junior school (grade five) through advanced middle school. (C. J. Kim 2006: 37) The curriculum was termed "foreign orthography". (Hannas 1997: 68; M. S. Kim 1999; J. K. Kim 2006) By 1969, the 2,000 characters mandated for instruction throughout the six years of advanced middle school were to receive two hours of instruction per week. (King 2007: 214) The Hanja instruction was distributed as follows: 1,500 for grades five through eight, and another 500 characters for grades nine and ten. In 1970, at which time Kim Il Sung observed that the students' achievement in Hanja was "weak", university students were supposed to learn an additional 1,000 characters, coming to a total of 3,000 characters. (Yi 1989: 372, cited in Hannas 1997: 6869; M. S. Kim 1999) Teachers were supposed to instruct students on how to write Chinese characters, identification of constituent character radicals, and practice the use of technical Sino-Korean vocabulary in the classroom. (Kuiwon 2014)

In addition to the observation that Hanja learning was relevant for North Koreans to keep informed about South Korea, Kim Il Sung's thinking was directly related to his plans to reunify the peninsula through revolution in the South. (King 2007: 214) After his pro- 
nouncement of the "Equal Emphasis Policy" in 1962, North Korea had launched a military buildup dedicating as much as 30 percent of its total budget to defense. Beyond the thinking related to political ties with China, Kim Il Sung increased the number and frequency of military provocations between 1967-1969, in what some historians have called "The Second Korean War". (Bolger 1991: 1-5) Kim's strategy was, in part, driven by the presence of widespread poverty in the South, political opposition to Park Chung Hee, and the United States increasing involvement and buildup in Vietnam. On a personal level, Kim Il Sung surely remembered his advantage as a young partisan having had a middle school education, which he had obtained while his family lived in Manchuria. (Lankov 2002: 51) Relative to the standards of the 1930s and 1940s, Kim Il Sung was an educated person and knowledge of Hanja was useful in his rise to power, at least among Korean partisans, many of whom were illiterate. (Suh 1988: 6) Most available materials strongly indicate that Kim believed that the North could successfully engineer a revolution in the South; the North Korean population would be at an educational disadvantage compared to the larger Southern population who had a better grasp of Hanja. (Szalontai 2005: 18)

In 1971, a new Hanmun textbook for use in North Korean university history departments was disseminated. The work contained 3,323 Hanja largely based on lexicon drawn from Kim Il Sung's Selected Works and the overwhelmingly political language of other communist publications. In March 1972, a "Mixed Script Reader" (Kuk-Hanmun tokbon) was published. Yi Yun-p'yo has speculated that the lexicon selected for the 1972 reader was based upon applicability to high-level Korean used in modern contexts. (Yi 1989: 372, cited in Hannas 1997: 68) In the preface of the reader, Kim Il Sung relates the mastery of Hanja to address potential problems with communication with South Koreans when the ultimate goal of national unification was achieved. (Song 2015: 485)

Amid these developments related to Hanja, North Korea from the 1960s through much of the 1980s was conducting language reform. The language reform policy of the Democratic People's Republic of Korea (North Korea) was based on communist ideology. This resulted in a removal of Sino-Korean terminologies, and a gradual simplification of speech levels, making North Korean speech appear more "egalitarian" than South Korean speech. (Yeon 2007: 151 and 
154) North Korea called their standard speech "Cultured Language" (Munhwaŏ), largely based on P'yŏngyang speech, and to a lesser degree, the idiolect of Kim Il Sung. (Kumatani 1990: 105-106) In the process of language reform, the North replaced many Japanese loanwords and Sino-Korean terms with newly coined native words. The North Korean government was able to solve the "homophone problem" that exists in Sino-Korean terms by simply deleting certain words with similar sounds from their lexicon. (Lee and Ramsey 2000: 309-310)

Kim Jong Il was named the successor to his father at the Sixth Party Congress in October of 1980. Thereafter, the younger Kim began to play an increasing role in issuing guidance and directing activities in the North. Throughout the 1980s, Kim Jong Il, while serving as the chief of the powerful North Korean National Defense Committee, often rendered guidance on the need to strengthen Hanja education in the North. (J. K. Kim 2006) After the death of Kim Il Sung in 1994, Kim Jong Il continued his father's directives regarding the importance of Hanja to North Korean education, this despite the fact that Hanja use was declining in South Korea. In a Hanja textbook published in during his years as leader, Kim Jong Il particularly noted that the preponderance of Korean scientific jargon was Sino-Korean. There had been some concerted efforts in the 1960s to "purify" scientific jargon particularly in the medical field that were heightened in the 1970s, but these efforts failed and North Korean scientists returned to using SinoKorean by the late 1980s. Kim Jong Il stated the following:

“To further develop our country's sciences and language, to achieve independent reunification of our fatherland, and to completely resolve our nation's problems, we must still learn Hanja”. (Kim Jong Il quoted in Kuiwon 2014)

There are numerous other quotes and comments attributed to Kim Jong Il related to Hanja education. In April 1994, with the publication of the text Cultured Language Learning (Munhwaŏ haksüp), Kim Jong Il pointed out that students must learn Hanja in order to properly speak the very "life of the Korean language". (J. K. Kim 2006) On 11 August 2000, while in Beijing, Kim Jong Il was reported to have criticized the prevalence of an "obstinate moral obligation" to Chosŏn'gŭl exclusivity. Lastly, on 18 June 2005, Kim emphasized that knowledge of Hanja was necessary so that the language of the two 
Koreas would not become "differentiated" (ijilhwa) from each other. (J. K. Kim 2006)

\subsection{South Korea}

The liberation of Korea and the subsequent occupation by American forces in the South brought expectations of change among Koreans. In the sector south of the thirty-eighth parallel, the trajectory of the American occupation provided a substantially different one compared to the Soviet occupation in the North. The Americans committed two serious errors. The first was an attempt to retain members of the hated former colonial administration until stability was established. This decision was reversed after strong public protest. Second, the American occupation forces immediately rejected the legitimacy of the people's committees which spontaneously emerged in August and September 1945 throughout Korea, conceiving of such organizations as being fronts for "leftist/communist" agitation. (Cumings 1981: 137142 and 267-268; Gills 1996: 34-37) The traditional American understanding of liberation and nation-building was not emphatically revolutionary, but rather, more about consensus building and institutional or procedural foundations for "democracy". The Americans were indecisive, blinded by their own projection of American democratic aspirations onto the Korean social setting, and usually failed to appropriately interpret the political dynamics of post-liberation Korea, which included demands for economic and social justice. (Henderson 1968: 113-136) United States forces, unlike their Soviet counterparts in the North, conceptualized the trusteeship as a means of forging institutional frameworks for establishing a left-right coalition government that would form the basis of a new state. (Taylor and Taylor 1995: 254; B. B. C. Oh 2002: 4-5; Kang 2005: 179-181)

The Americans have been criticized for dependence on English-language Korean interpreters, most of whom were well-educated and from the landed-interests of the yangban, or Koreans who had worked for, or in cooperation with the Japanese occupation government. The slow pace of land reform was an example of the vested 
interests stonewalling popular sentiment; land reform was not passed until 22 June 1949, only after much pressure from the Americans; the much awaited land was incrementally implemented throughout the decade of the 1950s. (Nahm 1996: 382) The emerging administration of Syngman Rhee in the Republic of Korea (1948-1960) depended on support of a police force composed of Koreans who had worked for the Japanese police force. Additionally, the media and the education system in the South, dominated by Japanese-era journalists, continued language use practices established during the Japanese occupation period, which meant the continued use of Hanja. This was consistent with the generally conservative character of the centers of power of South Korea. (B. B. C. Oh 2002: 5)

In the years of the American occupation of the South (19451948), the literacy rate in Korea was fairly low, with estimates ranging between 20-40 percent. Commencing in 1945, the Korean Language Society (Han'gŭl hakhoe) actively advocated Han'gŭl exclusivity and the eradication of all Hanja from Korean writing. In November 1945, the Korean Education Council (Chosŏn kyoyuk simüijhoe) (Hannas 1997: 69) moved to examine the issue of Hanja in education. On 8 December 1945, the council voted to eliminate Hanja from elementary and middle schools textbooks. An American official working for the Department of Education under control of the United States Army Military Government in Korea (USAMGIK) named Paul S. Anderson, wrote in 1948 of the difficulty posed by Chinese characters in the South; Anderson observed that Hanja prevented "mass literacy so essential in a modern nation" and that as long as it was essential to read Hanja literacy would "remain the possession of the educated elite". (Anderson 1948: 508-510, cited in King 2007: 215) While there were certainly forces in the South favoring the curtailment or outright abolition of Hanja, a number of factors conspired against them. First and foremost among these was the simple fact that, unlike in the North, where any and all individuals with former ties to local elites and the Japanese colonial administration were purged, and the United States military occupation officials in the South ended up leaving largely intact the members Japanese-educated elite and officialdom, all of whom were well-versed in Hanja. (King 2007: 215)

In June 1948 the Ministry of Education launched a "Reclaim Our Language" movement, and the Korean Language Society submitted a proposal. Han'gŭl-only usage was initially passed by the Nation- 
al Assembly on 30 September 1948, but was amended the next day under pressure from conservative, pro-Hanja elements to include the following caveat: "For the time being, however, Hanja may be used together with Han'gŭl". On 9 October 1948, South Korea enacted, "The Law Concerning Hangul Exclusivity" (Han'gŭl chŏnyong-e kwanhan pŏmnyul), also known as Law Number 6. (Hannas 1997: 69) The law stated, "Public documents of the Republic of Korea shall be in Han'gŭl; however, when necessary, mixed script can be used". (Han'gŭl chŏnyong-e kwanhan pormnyul chejŏng, 1948) The passing of the Han'gŭl Exclusivity Law was done in a post-independence period filled with nationalist fervor, without protracted debate. Some scholars have speculated that this was the beginning of the inconsistent South Korean policy variations concerning Hanja throughout the 1950s, 1960s, and 1970s. (King 2007: 215-216)

In 1951, the Ministry of Education published an official list of 1,260 characters for common use and recognition, of which 1,000 were to be learned in elementary and middle school. (King 2007: 216) By the end of 1953, however, South Korean law stipulated that students through the end of junior high school (grade eight), were to be taught 1,787 Hanja. (M. S. Kim 1999) Indeed, the government made attempts at officially proclaiming "Han'gŭl exclusivity" in 1954 and 1956, but with little or no success; the opposition within the government was unwilling to implement a Han'gŭl exclusivity program. (Sohn 1991: 196) However, the first "abolish illiteracy" (munmaeng t'oech 'i) campaign targeting adults was launched by the Ministries of Education, Interior, and Defense from 18 March to 31 May 1954, reducing adult illiteracy from 27.7 percent to 7.9 percent of the population. Basic literacy was defined as basic mastery of Han'gŭl, and the campaigns continued to be conducted every spring for the remainder of the decade. (Seth 2002: 92)

The Korean Language Society, after a decade of attacking the use of Hanja and advocating Han'gŭl exclusivity, finally convinced the government to approve new guidelines of a Revised Han'gúl Plan. The Council of Ministers, under pressure from Han'gŭl exclusivity proponents, decided to ban the use of characters, and beginning in August 1957, police were reportedly even given orders to remove any signs from businesses written in "foreign scripts", not just those in "Hanja", as well as attempting to extend the ban related to public notices and selected government documents. The media and educated 
Koreans, however, protested the plan as removing an important link to Korea's cultural heritage and the East Asian cultural context. (Song 2005: 166; Hannas 1997: 70; King 2007: 216) The law became fully implemented in January of 1958, when guidelines were promulgated requiring that all public documents should be in Han'gŭl. Despite the ban there was a caveat that if the word was difficult its Hanja would be written in parenthesis after it. (Sohn 1991: 196; Han'gŭl chŏnyong silch'ŏn'yogang sihaeng 1958)

Syngman Rhee frequently used instrumentalist nationalism, couched in anti-Japanese and anti-communist references, for the purpose of state and regime survival in the face of Communist threats both internal and external, and later to enforce notions of legitimacy, before, during and after the Korean War. The reversal of the Syngman Rhee administration regarding Han'gŭl exclusivity was a very political decision. The government likely saw the program helpful in bolstering its standing in a segment of the population, with little or no education, which still demanded social and economic justice (Y. P. Hong 1999: 151-152), particularly in light of the success of the Han'gŭl-only adult literacy campaigns.

Ultimately, the specific domestic political reasoning for the reversal was related to the decreasing public support for the regime, exemplified by the relatively successful presidential candidacy of Cho Bong-am, a Moscow-educated, former communist and popular progressive received 30 percent of the popular vote in the 1956 election. The popularity of his mass-centered economic policies, and uncompromising nationalist line "no United States, no Soviet Union" (Y. J. Kim 2015: 70), won favor with a number of South Koreans. Moreover, the increasing support for the opposition Democratic Party, particularly in rural areas, which had been a dependable source of support for Rhee's Liberal Party (Nahm 1996: 405; C. Y. Pak 1980: 149-150), was another motivation for garnering support among rural voters.

In November 1957, the number of Hanja for daily use was officially expanded to 1,300 . This had been designed to limit number of characters used in South Korean newspapers. The original 1957 guidelines for Han'gŭl exclusivity were not universally implemented, as many official documents from this time were still written in mixed script. During the late 1950s and early 1960s, it remained mandatory for South Korean public schools to teach students 1,000 Hanja starting from elementary school. Academics continued to recommend an in- 
crease in the number of characters taught. (Song 2015: 480; Kuiwon 2013) Then in February 1963 the government decided to return to mixed script in school texts and manuals; this would be fully implemented in 1965. The government decision was met with strong opposition, which included proposals to eliminate textbook Hanja in parentheses. In 1964, the Minister of Education published a list of 1,300 Chinese characters for instructional purposes (Song 2005: 166), with 600 to be taught in elementary schools, 400 in junior high schools, and 300 in high schools. (Sohn 1999: 77; Hannas 1997: 70)

The ascension of Park Chung Hee to power in the May Revolution of 1961 brought about abrupt economic changes. Park launched a program of export-led economic development, which as of the early 1960s, was a reflection of dependency theory. Dependency theory was an approach to economic development in contrast to modernization theory, originating in the plight of Latin American countries that were under "American exploitation", and were thus in a state of perpetual dependency. Dependency theory recommended export-led economic strategies for peripheral national economies. (McCormack 2011: 192) The legitimization of the 1961 coup was to portray Korea's past in an unfavorable light, suggesting an internal lack of political cohesion that invited foreign invasions, the loss of national identity, and the rise of flunkeyism as well as the lack of innovation in economic life and the resulting vicious circle of poverty and underdevelopment. (Moon and Jun 2011: 123) Park patterned his concept of economic nationalism based on prewar Imperial Japan's desire to achieve a "rich country, strong defense" (Japanese, fukoku kyōhei, Korean, pu'kuk kang'wi), the state-developmental model which included a commitment to rapid economic development and establishing a strong national defense. (J. H. Kim 1978: 6) But Park Chung Hee also espoused the importance of national morality (kungmin toŭi) as a necessary component of national reconstruction, (Y. J. Kim 2011: 96) a concept which Park consistently injected into the logic of the May Revolution and many of his policy decisions while serving as president of South Korea.

By 1966, however, Park began to realign his view of nationalism, with a new found rhetoric emphasizing the legacy of Korean traditions, as in his 1966 state of the union speech:

"In order to establish a firm national identity and to overcome social apathy, [South Korea] should reaffirm the superior legacies of [its] culture and tradi- 
tion and foster the creation of a new culture on the basis of these legacies". (Park Chung Hee quoted in Moon and Jun 2011: 123)

With this rediscovery of Korea's traditional national identity, Park began large public works programs to preserve and restore cultural relics and historical sites, as well as glorify national myths, symbols and ritual through the glorification of national heroes, including Admiral Yi Sun-sin (1545-1598) and King Sejong (1397-1450). Park launched a program of revival of the national spirit in 1968, an example being the introduction of the pledge of national allegiance. The Park Chung Hee regime placed a new emphasis on the "glorious national history", opening the Academy of Korean Studies, which literally means the "Institute of Korean Spiritual Culture", with the mission of establishing and constructing historical sites, museums and monuments to famous historical figures throughout the nation. The 1968 "Charter for National Education" (Kungmin kyoyuk hŏnjang) established a curriculum for primary and secondary schools rich in support for Park's economic nationalism. The phrase "We are born with the historical mission of restoring our nation", was to be memorialized by all students. The Charter made the subject of "national history" an obligatory subject in all universities. (Moon and Jun 2011: 123124) Park's political strategy was to strengthen his support among conservative voters by appealing to what were universally held notions of the Korean nation.

Characteristic of Park's adaptable nationalism were his early criticism of Confucianism and his attempt to establish Han'gŭl exclusivity. During Park Chung Hee's 1963 presidential campaign, the candidate criticized a famous Korean Confucian scholar from North Kyŏngsang Province, Park's native province and a key source of political support. The critique of Kim Song-il was that he and other Confucian scholars and officials had wasted national energy on "empty theory and futile debate" (kong'il kongron). Much of the conservative population responded negatively. During the 1970s, Park subsequently reversed himself, praising Confucian virtues of propriety and filial piety, and Korean Confucian scholars, to including affixing their images to Korean worn notes: Yulgok (Yi I) (1536-1584) on the 5,000 wŏn note in 1972, and T'oegye (Yi Hwang) (1501-1570) on the 1,000 wŏn note in 1976. (K. O. Kim 1996: 217-218; Moon and Jun, 2011: 123-124) 
Park Chung Hee's attempt to establish Han'gŭl exclusivity in the 1960s and early 1970s, in addition to revealing changes in his own nationalist politics, demonstrated the potential for controversy along the intersecting fault lines between Korean nationalism and the HanjaHan'gŭl binary. In 1966, Park prepared a secret memorandum in 1966 to commence a national program to gradually phase-out the use of Hanja in media and education. On 6 January 1968, the Korean Language Society appealed to Park to implement an all-Han'gŭl program applicable to both private and public sectors. (Hannas 1997: 70) Park reasoned that Han'gŭl exclusivity was suggestive of "modernity" and seemed to be consistent with his drive toward economic modernization.

On 14 March 1968, Park Chung Hee issued the following instructions to the relevant ministries: the Ministry of Education was to reduce the number of characters taught from 1,300 to 700 by 1969 . Afterward, by 1972, Hanja was to be totally eliminated from all textbooks. The Ministry of Public Information was to supervise and enforce the reduction of the number of Hanja used in newspapers and other printed materials from 2,000 characters used as of 1968 to 1,300 characters by 1969, 700 characters by 1970, and achieving Han'gŭl exclusivity by 1972 (Park Chung Hee chŏng'gwŏn-ŭi han'gŭl sich'aek yŏnp'yo 2005); the Ministry of Government Administration was to gradually overview the reduction of the number of Hanja used in public documents and business cards; and lastly, the Office of Court Administration was to gradually mark with Han'gul the family records, registration, registration entries, and lawsuits. (M. S. Kim 1973: 349-350, cited in Hannas 1997: 71; Kuiwon 2013)

Park Chung Hee, on 25 October 1968, publicly revealed his Han'gŭl exclusivity initiative, appealing nationalist sentiments:

\footnotetext{
"It has been over 520 years since King Sejong promulgated Han'gŭl. To not use Hangul exclusively and be reluctant is to be anti-independent, and not to have a modern way of thinking. It is behavior that drives many of our countrymen, who do not know Hanja, away from our culture". (Park Chung Hee quoted in Kuiwon 2013)
}

The new policy, his "Five-Year Hangul Exclusivity Plan" (Han'gŭl chŏnyong o-kae-nyŏn kyehoek), also known as "Prime Minister's Instruction No. 68" was to be accomplished through legislative and ex- 
ecutive means. Adding to the momentum of implementation, a further change in policy away from Hanja occurred in 1968-1969 when a Committee for the Exclusive Usage of Han'gŭl was created by the President of South Korea and the Minister of National Defense announced that the Korean military would use only Han'gǔl in its written materials. (King 2007: 216) Invoking the spirit of national independence, the government also banned Hanja from all school manuals in 1969. (Kuiwon 2013) The deadline for total elimination of Hanja was later advanced to 1 January 1970, to preempt countermoves by opposition. Park Chung Hee emphasized it would be illegal to teach Hanja and use mixed script textbooks in public schools in all grades, from elementary school to high school. By 1970, most basic textbooks for South Korean students had been rewritten into an all-Han'gŭl form. The propaganda stating that Korea was entering the new "Han'gŭl Age" (Han'gŭl sedae) started proliferating throughout Korean society. (Hannas 1997: 70-71; Kuiwon 2013)

The initiative sparked intense political debate. A poll by the Joongang Ilbo in 1970, revealed a deep division among South Koreans, with only 54 percent of those surveyed in support of the plan. In addition, many academics, writers, and journalists voiced their opposition to the initiative. Some went as far as calling the Hangul Exclusivity initiative unconstitutional. After public outcry, Park Chung Hee attempted to placate the opposition by stating that he personally found Hanja important to Korean culture and history. (Kuiwon 2013)

In December 1971, the Park Chung Hee administration reversed its position, and ordered the teaching of Hanja in public schools. The impetus for the reversal appears to have been at least three considerations related to domestic politics. First, an open petition of 140 prominent citizens of diverse political persuasions expressed their opposition to an all-Han'gŭl program, and proposed a reintroduction of Hanja education. (Hannas 1997: 71) Second, Park's political confidence was undoubtedly eroded from his narrow victory over Kim Dae Jung in the presidential election held on 27 April 1971. Park won with a margin of victory of only 946,928 votes. Third, Kim Dae Jung's campaign rhetoric of "mass participatory economics" and scathing denunciations of the Park administration as corrupt fed into popular dissatisfaction with the government's failure to address a broad range of social and economic issues stemming from rapid development. Social unrest continued for the remainder of the year until 
Park Chung Hee declared a state of national emergency on 6 December 1971. (H. A. Kim 2004: 124-126; Kang 2005: 206-207)

In 1972, the government only permitted optional Hanja education in middle schools and high schools. It still maintained the ban on Hanja education in elementary schools and the prohibition on mixed script in textbooks other than Hanja textbooks. While many middle and high schools in Korea did restore Hanja education, there were plenty that did not. The South Korean government in 1972 published a new list of 1,800 basic Hanja for secondary school education, and then officially reintroduced Hanja into South Korean school textbooks in 1974. A politically sustainable stasis was struck in 1976 when the Ministry of Education agreed to keep Hanja education out of elementary schools and the 1,800 Hanja would be taught in special courses, rather that part of language and humanities instruction. (Hannas 1997: 71-72)

Clarity of meaning and ease of use was a controversy regarding the Han'gŭl exclusivity law, which as of 1970, provided for the eventual elimination of difficult Sino-Korean terms in government statutes. Supporters of Han'gŭl exclusivity argued that comprehensibility would be enhanced if "opaque Sino-Korean words" were replaced by pure Korean terminologies. Park Chung Hee himself criticized this argument, denouncing the wholesale conversion to pure Korean words as "too unrealistic", and questioned the notion of using "overly contrived pure Korean coinages for perfectly natural, wellestablished Sino-Korean words". (Park 1989: 130 and 137, cited in Lovmo 1999) In August 1977, the Ministry of Education once again noted that because of ambiguity from Han'gŭl-only in high-level vocabulary, publishers were required to use English language glossaries for such all-Han'gŭl terminologies. (Hannas 1997: 72-73)

The result of Park Chung Hee's attempt to establish Han'gŭl exclusivity was that Koreans who attended school during this time and a large percentage of the subsequent generations were never formally taught Hanja. In the following decades, the percentage of Hanja use in Korean writing plummeted. The authoritarian regime of Chun Doo Hwan maintained fragments of Park Chung Hee's Han'gŭl exclusivity policy, such as discouraging the reading of Confucian classics viewing them as subversive anti-authoritarian material. A 1956 survey of South Korean adults revealed that a majority read a pure Han'gŭl text slower and with more difficulties than a mixed-script text. By 1977, 
that had changed dramatically, with a reported 80 percent of surveyed adults able to read pure Han'gŭl text with greater facility than mixedscript texts. (Taylor and Taylor 1983: 90; Kuiwon 2013)

Over the last two decades, scholarly discourse has proliferated regarding two byproducts of globalization: integration and fragmentation. Global incursion into the national space of a nation, that is, a bounded community, is asserted be accompanied by a rise in nationalism. (Sabanadze 2010) Anthony D. Smith observed that globalization, as with modernization, inevitably produces social and cultural disruption, and nation-states often react to upheaval by promoting ethnic and national solidarity. (Smith 1995, cited in Shin 2006: 214) In the case of South Korea, this was demonstrable in the paradigmatic changes related to globalization in the post-Cold War era (S. B. Kim et al. 2002: 7-8), and in the "script nationalism" in both Koreas, in which Han'gŭl (Chosŏn'gŭl) have increasingly been esteemed as a symbol of national purity and a defense against foreign influences resulting from modernization and globalization. (King 2007: 232-233)

Shin Gi-Wook has correlated globalization/modernization and the assertion of nationalism in the political behaviors of the administrations of Park Chung Hee, Kim Young Sam, and Kim Dae Jung. The relationship between Park's attempt at Han'gŭl exclusivity and his nationalist shift in 1966 which included the resurrection of nationalist symbols and figures, and his drive to national economic modernity, according to Shin, parallels Kim Young Sam's emphasis on the history of Korea's democratic heritage by promoting Korean heritage and culture, while pursuing a globalization (segyehwa) strategy. (Shin 2006: 214-216; J. K. C. Oh 1999: 135-136) In the 1990s, organizations such as the Research Institute for Education in the Korean Language and Writing spearheaded a drive to restore mixed-script, as exemplified by such books as Research on the Orthography of the National Language. (Taylor and Taylor, 2014: 177) Books the In 1993, for the first time in 30 years all public schools in all grades in South Korea were allowed to teach Hanja. (Kuiwon 2013) Interest in Hanja among South Koreans in the 1990s expanded because of the potential for economic opportunities with China and Japan. (S. H. Park 1994: 34); however, Taylor and Taylor (2014: 177) suggest that the trend, was in part, prompted by complaints of older readers to restore the use of Hanja in daily South Korean newspapers. 
Kim Dae Jung pursued reinvigoration of Hanja more than all post-authoritarian presidents, and made many attempts at reversing Han'gŭl exclusivity policies. In 1999, one year after his election, he announced his intentions to reintroduce Hanja in public documents and in education. This was met with great resistance. (Song 2005: 167) The government's announcement of plans to reintroduce HanjaHan'gŭl parallel use was immediately the object of widespread protests by the forces of the proponents of Hangul exclusivity. (J. H. Lee 1999) Typically, the criticisms included concerns over the academic burden on students at the cost of other subjects, and called the reintroduction of Hanja was an "affront to national sovereignty" and a "regressive" act. During the Kim Dae Jung presidency, Hanja in a smaller font size was placed below Han'gŭl, on road signs, bus stops, and on subway signs. In education, Classical Chinese was re-introduced as a one year elective in public high schools in 1999 and Hanja Proficiency Test (Hanja'nüngnyŏkgŏmsasihŏm) results above a certain ranking were admitted as a publicly recognized qualification (Kukka'gong 'injagyǒk) in 2001. (Song 2005: 167; Kuiwon 2013)

\section{Conclusion}

The staying power of the bifurcated narrative related to Hanja and Han'gŭl (Chosŏn'gŭl), still prominent in both Koreas, remains strong. In North Korea, despite Chosŏn'gŭl exclusivity in the media and the extolling of the script as being a superior writing script, early in the reign of the new North Korean leader, Kim Jong Un, the North Korean government reported that the new leader had composed a Classical Chinese poem at the age of three. The importance of Hanja was reiterated in a North Korean Hanja textbook published in 2013, in which Kim Jong Un explains to students that Hanja education is not only necessary to improve Korean language vocabulary, or to be used in trade with neighboring countries, but is to be mastered as a vehicle to bring about "revolution in South Korea". Evidently, the symbolic power of mastery of Hanja is still potent for some North Koreans. Yet, despite official support of Hanja learning, there appears to be a lack of 
uniformity in Hanja education in the North. Most recent North Korean refugees, who are often from the lower classes, have never been exposed to the script. Anecdotal evidence from North Korean defectors who have had Hanja education strongly suggests a rudimentary retention of Hanja. (Kuiwon 2014)

Korean nationalism's digraphic conflict is a lively topic in the South. In 2013, for the first time since Park Chung Hee's Han'gŭl exclusivity program, all public elementary schools in Seoul were permitted to teach Hanja causing contentious debate. (Cho 2013) The results of a 2014 Gallup poll on attitudes related to Hanja was revealing. Pollsters asked was whether Hanja was "Korean" or "foreign." The results were as follows: 47 percent responded Hanja was "foreign"; 48 percent answered it was "Korean"; and 7 percent were undecided or did not answer. This was statistically the same as the answers from a 2002 poll. (Han'guk sayong-e daehan insik chosa 2002/2014nyon pigyo) The results of the two polls underscores the relationship between script and identity and the continuing Korean digraphic conflict between Hanja and Han'gŭl. (Haarmann 1993: 144)

A 2014 government study on the issue of Hanja instruction in South Korea recommended no expansion past the current 1,800 Hanja limit through high school. The document states:

"The flood of nationalism, which had aimed to nurture the 'people' to be loyal through some limited language education, drove Chinese character into being considered not only a vestige of Japanese imperialism, but also as an outdated, insignificant relic". (W. J. Kim 2014: 7-9)

The study recommends that the educational energies of students might be better spent "growing the right personality" and cultivating "reasonable values", which would, according to the study, better accommodate "curriculum to the modern demands of education". (W. J. Kim 2014: 7) The study's conclusions may reflect an attempt by the Park Geun Hye administration to strike a medial position between a divided electorate. Curiously, the argument of focusing education on cardinal moral values seems a feint reflection of Chu Si-gyŏng's arguments in the late nineteenth century; perhaps a testimony to the vitality of Korean nationalism's conflicted embrace of the Hanja-Han'gŭl binary.

A survey of the policies of both Koreas over half a century related to the use and instruction of Hanja and Han'gŭl (Chosǒn' gŭl) indicate that both scripts can serve the instrumental function of repre- 
senting the virtues and identity of the Korean nation, but not with graceful synchronicity. Korea's digraphic conflict will likely continue to be intractable in the shadow of nationalism's formation related to script. Expressing the views of the author of this article is a paraphrasing Chen Ming-Jer: this will not transcend paradox while lost from the Middle Way. (Chen 2002: 183-184)

A daunting ritual in composing an article is deriving an appropriate title. The intellectual trajectory of this "thought piece" seemed reasonably straightforward, at first. However, as the layers of the subject were unfolded, the initial title, though having topical sufficiency, was wanting, perhaps in need of metaphor to capture something of the "soul of the article." The author searched Korean language poetry, both traditional and modern, looking for paradox. At last, contained in the below cited poem was something useful.

\section{八月十五夜 (팔월십오야) (추석날밤)}

The Night of the 15th Day of the Eighth Month (Ch'usŏk Night)

李荇 (이행) (1478-1534)

Yi Haeng (1478-1534)

\section{平生交舊盡调零 (평생교구진조령)}

The friends that I have made in life are all dead;

\section{白髮相看影與形 (백발상간영여형)}

My shadow and form, with earlocks white, take each other in.

\section{正是高樓明月夜 (정시고루명월야)}

Atop a high loftbuilding, the moon is bright tonight,

\section{笛聲凄斷不堪聽 (적성처단불감청)}

And I cannot bear the cold sound of the flute.

Yi Haeng, a civil official working in Kyŏngsang Province, wrote this poem on Ch'usŏk night in the year 1520. In the poem, the speaker's melancholy is clearly pronounced. It has been speculated that Yi was considering lost "friends", some of whom were victims of literary purges in 1504 and 1519 . In the second line, the poet uses a common poetic expression "shadow and form" (yŏng yŏ hyŏng), also translated as "shadow and body". The poet is lamenting those he has 
lost, and that his only company are his own shadow and body, gazing at one another in the moonlight. Min Pyong-su's analysis and Michael J. Miller's translation (Min, 1999: 108-110) brought forth an explanatory metaphor, part of which was used for the title, along with Harald Haarmann's use of the phrase "digraphic conflict". (1993: 144) The speaker in the poem projects his internal landscape onto the world around him. It seems that more than through linear thinking, the intersections between Korean nationalism and the Hanja-Han'gŭl binary are better expressed in the language of this poem; the poem renders in words the ethereal confluence of thought and identities that have travelled on the arcing light of the dead, across memory, and across time.

\section{References}

Anderson, Paul S. 1948. Korean Language Reform. Modern Language Journal, Vol. 32, 508-511.

Armstrong, Charles K. 2003. The North Korean Revolution, 19451950. Ithaca, NY: Cornell University Press.

Bloom, William. 1993. Personal Identity, National Identity, and International Relations. Cambridge: Cambridge University Press.

Bolger, Daniel P. 1991. Scenes from an Unfinished War: LowIntensity Conflict-Korea, 1966-1969. Leavenworth Paper, No. 19. Fort Leavenworth, KS: U. S. Army Command and General Staff College.

Caprio, Mark E. and Yu Jia. 2009. Legacies of Empire and Occupation: The Making of the Korean Diaspora in Japan. The AsiaPacific Journal, Vol. 37-3-09, September 14. http://japanfocus.org/-yu-jia/3221/article.html (accessed on 20 September 2015).

Chen, Ming-Jer. 2002. Transcending Paradox: The Chinese Middle Way "Perspective". Asia Pacific Journal of Management, Vol. 19, Issue 2/3, August, 179-199. http://dx.doi.org/10.1023/A: 1022024730957 (accessed 30 September 2015).

Cho, Chung-un. 2013. Hangeul advocates oppose Hanja classes. Korea Herald, (English Edition), 3 July 2013. http:// www.koreaherald.com/view.php?ud=20130703000818 
(accessed on 2 September 2015).

Cumings, Bruce 1981. The Origins of the Korean War: Liberation and the Emergence of Separate Regimes, 1945-1947. Princeton, NJ: Princeton University Press.

Eckert, Carter, J., Ki-baek Lee, Young Ick Lew, Michael Robinson, and Edward W. Wagner. 1990. Korea, Old and New: A History. Seoul: Ilchokak Publishers.

Gills, Barry K. 1996. Korea versus Korea: A Case of Contested Legitimacy. London and New York: Routledge.

Haarmann, Harald. 1993. The Emergence of Korean Script as a Symbol of Korean National Identity. In: The Earliest Stage of Language Planning: The "First Congress" Phenomenon. Ed. Joshua A. Fishman. 143-158. Berlin: Mouton de Gruyter.

Haas, Ernst B. 1997. Nationalism, Liberalism, and Progress: The Rise and Decline of Nationalism. Ithaca, NY: Cornell University Press.

Han'guk sayong-e daehan insik chosa - 2002/2014nyŏn pigyo [Survey on attitudes related to the use of hanja - A comparison of the years 2002 and 2014] (2014). Seoul: Korea Gallup. http://www.gallup.co.kr/gallupdb/reportContent.asp?seqNo=583 (accessed on 15 September 2015).

Han'gŭl chŏnyong-e kwanhan pormnyul chejŏng (Enactment of the law concerning han'gŭl exclusivity] (1948). National Archives of Korea. Seoul: Government of the Republic of Korea. http://theme.archives.go.kr/next/hangeulPolicy/practice.do (accessed on 15 September 2015).

Han'gŭl chŏnyong silch'ŏn'yogang sihaeng 1958nyŏn [Implementation of the han'gŭl exclusivity policy] (1958). National Archives of Korea. Seoul: Government of the Republic of Korea. http://theme.archives.go.kr/next/hangeulPolicy/practice.do (accessed on 15 September 2015)

Hannas, William C. 1991. Korean Views on Writing Reform. In: Schriftestschrift: Essays in Honor of John DeFrancis on His Eightieth Birthday. Sino-Platonic Papers \#27. Ed. Victor H. Mair. 85-94. Philadelphia: University of Pennsylvania.

Hannas, William C. 1997. Asia's Orthographic Dilemma. Honolulu: University of Hawai'i Press.

Hatori, Reiko. 1991. Pukhan-ǔi hanja kyoyuksa [The history of Hanja education in North Korea]. Pukhan-ǔi Chosŏn'ŏ yŏn'gusa, 1945- 
1990 [The history of Korean language research in North Korea, 1945-1990], Vol. 2. Ed. Min-su Kim. 266-290. Seoul: Nokjin.

Henderson, Gregory. 1968. Korea: Politics of the Vortex. Cambridge, MA and London: Harvard University Press.

Hobsbawm, Eric. 1996. Language, Culture, and National Identity. Social Research, Vol. 63, No. 4, Winter 1996, 1065-1080.

Hong, Yong-Pyo 1999. State Security and Regime Security: President Syngman Rhee and the Insecurity Dilemma in South Korea, 1953-60. New York: Palgrave Macmillan.

Horowitz, Shale, Uk Heo, and Alexander C. Tan (2007). Democratization and National Identity in the China-Taiwan and Korean Conflicts. In: Identity and Change in East Asia Conflicts. Eds. Shale Horowitz, Uk Heo, and Alexander C. Tan. 1-26. New York: Palgrave Macmillan.

Janasiak, Christoph Jan. 2012. Wczesna prasa-modernizacja pisma $i$ języka [The modern Korean press - modernization of writing and language]. Warsaw: Linguistica Asiatica Orientalia.

Jenkins, Richard. 1997. Rethinking Ethnicity: Arguments and Explorations. Thousand Oaks, CA: Sage Publications.

Jepperson, Ronald J., Alexander Wendt, and Peter J. Katzenstein. 1996. Norms, Identity, and Culture in National Security. In: The Culture of National Security: Norms and Identity in World Politics. Ed. Peter J. Katzenstein. 33-75. New York: Columbia University Press.

Kang, Man-gil 2005. A History of Contemporary Korea. Trans. John B. Duncan. Folkestone, Kent: Global Oriental Ltd.

Kim, Chin-wu 1978. Linguistics and Language Policies in North Korea. Korean Studies, Vol. 2, 158-175. Honolulu: Faculty Center for Korean Studies, University of Hawai'i.

Kim, Hyung-A. 2004. Korea's Development under Park Chung Hee: Rapid Industrialization, 1961-79. London and New York: Routledge.

Kim, Jai-Hyup. 1978. The Garrison State in Pre-War Japan and PostWar Korea: A Comparative Analysis of Military Politics. Washington, D.C.: University Press of America.

Kim, Jeong Kang. 2006. Hanja pyegi'nŭn taegwao...kukhan honyongŭro 'dong asiasŏng' sallyŏnaeja [Disposing of Hanja is a big mistake...Let's revive 'East Asian characters' through mixed-script]. Sindonga, No. 561, 526-539. http://shindonga.donga.com/docs/ 
/magazine/shin/2006/06/12/200606120500049/20060612050004 96.html (accessed on 27 May 2015).

Kim, Joungwon. 1975. Divided Korea: The Politics of Development, 1945-1972. Elizabeth, NJ and Seoul: Hollym International Corp.

Kim, Kwang-ok. 1996. The Reproduction of Confucian Culture in Contemporary Korea: An Anthropological Study. In: Confucian Traditions in East Asian Modernity: Moral Education and Economic Culture in Japan and the Four Mini-Dragons. Ed. Weiming Tu. 202-227. Cambridge, MA and London: Harvard University Press.

Kim, Min-su. 1973. Kuk'ŏ chŏngch'aekron [Discussing national language policy]. Seoul: Koryŏdaehakyo ch'ulp'anbu.

Kim, Min-su. 1999. Pukhan-ŭi hanja kyoyuk [North Korea's hanja education]. http://www.korean.go.kr/nkview/nklife/1999 2/ 95. html (accessed on 12 June 2015).

Kim, Samuel S. 2004. Northeast Asia in the Local-Regional-Global Nexus: Multiple Challenges and Contending Explanations. In: The International Relations of Northeast Asia. Ed. Samuel S. Kim. 3-64. Lanham, MD: Rowman \& Littlefield Publishers.

Kim, Sang-bae, Chin-yŏng Kim, and Chi-yŏn Kim. 2002. Segyehwasidae-ŭi ŏn'ŏminjokjuŭi-wa chŏngbohwajŏllyak [The era of globalization, language nationalism and informatization strategies], Kwach'ŏn-si: Chŏngbot'ongsin chŏngch'aek yŏn'guwŏn.

Kim, Woo-jeong. 2014. Hanjagyoyuk-ŭi hyŏnan-gwa kwaje sŏng'gyŏk, mokp'yo, iron-üi kyŏmhae [Pending issues and problems in relations to Chinese character education - discussing features, goals and theories of education]. $35^{\text {th }}$ Edition. Seoul: Han'gukhanja-hanmun mun'gyoyukhakhoe.

Kim, Young Jak. 2011. Park Chung Hee's Governing Ideas: Impact on National Consciousness and Identity. Reassessing the Park Chung Hee Era, 1961-1979: Development, Political Thought, Democracy \& Cultural Influence. Eds. Hyung-A Kim and Clark W. Sorensen. 95-106. Seattle: University of Washington Press.

Kim, Yunjong. 2015. The Failure of Socialism in South Korea: 19452007. Abingdon, Oxon and New York: Routledge.

King, Ross. 2007. Chapter 10. North and South Koreas. In: Language and National Identity in Asia. Ed. Andrew Simpson. 200-234. Oxford: Oxford University Press. http://www.academia.edu/ 13358623/Language_and_national_identity_in_the_Koreas (accessed on 28 May 2015).

Kuiwon Blog. 2013. On Hangul Supremacy and Exclusivity - Hangul Under the Dictators. https://kuiwon.wordpress.com/ 2013/10/10/ 
on-hangul-supremacy-and-exclusivity-hangul-under-thedictators/ (accessed on 15 May 2015).

Kuiwon Blog. 2014. A Look into Hanja Education in North Korea. https://kuiwon.wordpress.com/2014/12/28/a-look-into-hanjaeducation-in-north-korea/ (accessed on 15 May 2015).

Kumatani, Akiyasu. 1990. Language Policies of North Korea. International Journal of the Sociology of Language, Vol. 82, 88-107. http://kuir.jm.kansai-u.ac.jp/dspace/handle/10112/6959 (accessed on 24 May 2015).

Lankov, Andrei N. 2002. From Stalin to Kim Il Sung: The Formation of North Korea, 1945-1960. London: C. Hurst \& Co. (Publishers) Ltd.

Lee, Hi-seung. 1973. Recollections of the Korean Language Society Incident. In: Listening to Korea. Ed. Marshall Pihl. 19-42. New York: Praeger.

Lee, Iksop and S. Robert Ramsey. 2000. The Korean Language. Albany, NY: State University of New York Press.

Lee, Jun-ho. 1999. Controversy Over Co-use Of Hanja Growing. Chosun Ilbo (English Edition), 2 October 1999. http://english. chosun.com/site/data/html_dir/1999/02/10/1999021061505.html (accessed on 3 September 2015) .

Lovmo, Mark S. 1999. Language Purism in Korea. http://dokdoresearch.com/ gallery 15.html (accessed on 20 May 2015).

McCormack, Gavin. 2011. The Park Chung Hee Era and the Genesis of Trans-Border Civil Society. Reassessing the Park Chung Hee Era, 1961-1979: Development, Political Thought, Democracy \& Cultural Influence. Eds. Hyung-A Kim and Clark W. Sorensen. 187-204. Seattle: University of Washington Press.

Min, Pyong-su. 1999. Korean Poetry in Classical Chinese: Encounters between Man and Nature. Trans. Michael J. Miller. Seoul: Somyong Publishing.

Moon, Chung-in and Byung-joon Jun. 2011. Modernization Strategy: Ideas and Influences. In: The Park Chung Hee Era: The Transformation of South Korea. Eds. Byung-Kook Kim and Ezra F. Vogel. 115-139. Cambridge, MA and London: Harvard University Press.

Nahm, Andrew C. 1996. Korea: Tradition and Transformation - A History of the Korean People. Elizabeth, NJ and Seoul: Hollym International Corp.

Oh, Bonnie B. C. 2002. Introduction: The Setting. In: Korea Under the American Military Government, 1945-1948. Ed. Bonnie B. C. Oh. 1-12. Westport, CT: Praeger Publishers. 
Oh, John Kie-chiang. 1999. Korean Politics: The Quest for Democratization and Economic Development. Ithaca, NY: Cornell University Press.

Pak, Chi-Young. 1980. Political Opposition in Korea, 1945-1960. Seoul: Seoul National University Press.

Park Chung Hee chŏng'gwŏn-ŭi hangŭl sich'aek yŏnp'yo [A chronology of the hangŭl measures of the Park Chung Hee regime] 2005. Seoul: Han'gŭl hakhoe.

Park, Nahm-Sheik. 1989. Language Purism in Korea Today. In: The Politics of Language Purism. Eds. Björn H. Jernudd and Michael J. Shapiro. 113-140. Berlin: Mouton de Gruyter.

Park, Seong-ho. 1994. Korea Opts for Chinese Characters. New Straits Times, 30 May 1994, 34.

Peattie, Mark. 1984. Japanese Attitudes Toward Colonialism, 18951945. In: The Japanese Colonial Empire, 1895-1945. Eds. Ramon Myers and Mark Peattie. 80-127. Princeton, NJ: Princeton University Press.

Popov, Vladimir N. 1958. Razvitie narodnogo obrazovaniia v severnoi koree, 1945-1956 [The development of public education in North Korea, 1945-1956]. In: Koreia: Istoriia i ekonomika [Korea: History and economics]. Ed. Igor S. Kazakevich. 188-207. Moscow: Izdatel'stvo Vostochnoi Literatury.

Robinson, Michael E. 1988. Cultural Nationalism in Colonial Korea, 1920-1925. Seattle: University of Washington Press.

Robinson, Michael E. 2007. Korea's Twentieth-Century Odyssey: A Short History. Honolulu: University of Hawai'i Press.

Sabanadze, Natalia. 2010. Chapter 2. Nationalism Resurgent: Central Paradox of the Global Era. In: Globalization and Nationalism: The Cases of Georgia and the Basque Country. 15-34. Budapest: Central European University Press. http://books.openedition.org/ ceup/571 (accessed on 18 September 2015).

Scalapino, Robert A. and Chong-Sik Lee. 1972. Communism in Korea: The Movement. Vol. 1. Berkeley, CA: University of California Press.

Seth, Michael J. 2002. Education Fever: Society, Politics, and the Pursuit of Schooling in South Korea. Honolulu: University of Hawai'i Press.

Shin, Gi-Wook. 2006. Ethnic Nationalism in Korea: Genealogy, Politics and Legacy. Stanford, CA: Stanford University Press. 
Shipper, Apichai W. 2010. Nationalisms of and Against Zainichi Koreans. Asian Politics \& Policy, Vol. 1, No. 2, January/March, 5575.

Smith, Anthony D. 1995. Nations and Nationalism in a Global Era. Cambridge: Polity Press.

Sohn, Ho-min. 1991. Language Policies and Language Divergence in the Two Koreas. In: Schriftfestschrift: Essays in Honor of John DeFrancis on His Eightieth Birthday. Sino-Platonic Papers \#27. Ed. Victor H. Mair. 95-102. Philadelphia: University of Pennsylvania.

Sohn, Ho-min. 1999. The Korean Language. Cambridge and New York: Cambridge University Press.

Song, Jae Jung. 1994. Language Policies in North and South Korea: Divergence and Convergence. Language Quarterly, Vol. 32, No. 1, Summer/Fall, 205-212.

Song, Jae Jung. 2001. North and South Korea: Language Policies of Divergence and Convergence. In: Language Planning and Language Policies: East Asian Perspectives. Eds. Nanette Gottlieb, and Ping Chen. 129-158. Richmond, Surrey: Curzon Press.

Song, Jae Jung. 2005. The Korean Language: Structure, Use and Context. Abingdon, Oxon and New York: Routledge.

Song, Jae Jung. 2015. Language Policies in North and South Korea. In: The Handbook of Korean Linguistics. Eds. Lucien Brown and Jaehoon Yoon. 477-491. Chichester, West Sussex: John Wiley \& Sons, Inc.

Suh, Dae-Sook. 1967. The Korean Communist Movement, 1918-1948. Princeton, NJ: Princeton University Press.

Suh, Dae-Sook. 1988. Kim Il Sung: The North Korean Leader. New York: Columbia University Press.

Szalontai, Balázs. 2005. Kim Il Sung in the Khrushchev Era: SovietDPRK Relations and the Roots of North Korean Despotism, 1953-1964. Chicago: Stanford University Press.

Taylor, Insup and M. Martin Taylor. 1983. The Psychology of Reading. New York: Academic Press, Inc.

Taylor, Insup and M. Martin Taylor. 1995. Writing and Literacy in Chinese, Korean and Japanese. Amsterdam: John Benjamins.

Taylor, Insup and M. Martin Taylor. 2014. Revised Edition. Writing and Literacy in Chinese, Korean and Japanese. Amsterdam: John Benjamins.

Weathersby, Kathryn. 1993. Soviet Aims in Korea and the Origins of the Korean War, 1945-1950: New Evidence from Russian Archives. Working Paper No. 8, Cold War International History 
Project. Washington, D.C.: Woodrow Wilson International Center for Scholars.

Wendt, Alexander. 1992. Anarchy Is What States Make of It: The Social Construction of Power Politics. International Organization, Vol. 46, No. 2, 391-425.

Yeon, Jaehoon. 2007. Chapter 11. How Different is Pyongyang Speech from Seoul Speech? In: Korea: The Past and the Present. Eds. Susan Pares and James E. Hoare. 147-155. London: Global Oriental. http://eprints.soas.ac.uk/10277/ (accessed on 27 September 2015).

Yi, Yun-p'yo. 1989. "Pukhan-ŭi hanja kyoyuk-e daehayŏ" [On North Korea's Chinese character education]. In: Pukhan-ŭi ŏhak hyŏngmyŏng [North Korea's linguistic revolution]. Ed. Min-su Kim. Seoul: Tosŏch'ulp'an paek'ŭi. 